\title{
PENERAPAN MODEL PEMBELAJARAN REALISTIC MATHEMATICS EDUCATION UNTUK MENINGKATKAN KEMAMPUAN KOMUNIKASI MATEMATIS MENGGUNAKAN LEMBAR KERJA SISWA
}

\author{
${ }^{1}$ Restu Melawati \\ ${ }^{1}$ Pendidikan Matematika, Fakultas Keguruan dan Ilmu Pendidikan, Universitas Muhammadiyah Sukabumi \\ Restumellawati67@gmail.com
}

\begin{abstract}
Abstrak
Pembelajaran matematika di sekolah dipilih untuk mengembangkan kemampuan dan kepribadian siswa agar berguna ketika terjun dimasyarakat, maka dari itu dalam proses pembelajaran siswa harus dihadapkan pada situasi kehidupan nyata. Realistic mathematics education (RME) merupakan salah satu model pembelajaran yang menggunakan permasalahan kontekstual, untuk memudahkan siswa dalam memahami mata pelajaran matematika. Dalam penerapan model pembelajaran RME dapat menggunakan bahan ajar berupa lembar kerja siswa, agar pembelajaran menjadi terarah dan efektif. Dalam sederet aktivitas yang dilakukan pada proses pembelajaran ini maka akan terbentuk kemampuan komunikasi matematis siswa, karena siswa berperan aktif dalam pembelajaran. Kemampuan komunikasi inilah yang akan membantu siswa dalam menyelesaikan masalah baik secara lisan dan tulisan serta mengembangkan kemampuan dan kepribadian.
\end{abstract}

Kata Kunci: RME, Lembar Kerja Siswa, Komunikasi Matematis.

\section{PENDAHULUAN}

Elea Tinggih matematika berarti ilmu pengetahuan yang diperoleh dengan bernalar (Agustiana et al., 2019; Karyanti \& Komarudin, 2017). Matematika merupakan ilmu dasar yang terus mengalami perkembangan baik dalam segi teori maupun segi penerapannya (Nurjanatin dkk, 2017) Sebagai ilmu dasar matematika wajib dipelajari di tingkat sekolah menengah.

Matematika yang dipelajari ditingkat sekolah dikenal sebagai matematika sekolah (school mathematics) Matematika sekolah adalah bagian-bagian matematikayang dipilih atas dasar makna kependidikan yaitu untuk mengembangkan kemampuan dan kepribadian siswa serta tuntunan perkembangan yang nyata dari lingkungan hidup yang senantiasa berkembang seiring dengan kemajuan ilmu dan teknologi (Karyanti \& Komarudin, 2017; Ningsih, 2014; Suherman et al., 2018).

Namun kenyataannya dalam pembelajaran matematika di sekolah menengah khususnya tingkat SMK masih banyak guru yang menggunakan model pembelajaran konvensional, dimana siswa hanya mendengarkan pejelasan guru. Serta guru hanya menggunakan sumber dari buku paket yang isinya hanya sekumpulan rumus-rumus dan contoh soal yang abstrak. Pada akhirnya siswa menjadi sulit untuk memahami dan mempelajari materi yang diberikan, yang mengakibatkan siwa tidak mampu mengkomunikasikan permasalahan matematika secara lisan maupun tulisan dan siswa menjadi pasif dalam proses pembelajaran.

Padahal seharusnya siswa di tingkat SMK harus sudah mampu mengkomunikasikan berbagai informasi yang telah mereka ketahui, termasuk ketika pembelajaran di sekolah. Hal ini disebabkan pada proses pembelajarannya siswa tidak dihadapkan pada permasalahan yang ada pada kehidupan sehari-hari, namun langsung dihadapkan pada permasalahan yang abstrak.

Menurut Piaget (Alhaddad, 2012) seorang anak atau siwa dapat memahami suatu permasalahan yang abstrak jika sudah melewati tahap operasi konkrit yaitu tahap dimana seorang anak mampu menyelesaikan masalah berdasarkan apa yang telah dia alami atau yang ada pada kehidupan nyata anak tersebut. Sehingga anak tersebut mampu menyelesaikan permasalahan secara abstrak dikemudian hari.

Maka, pembelajaran matematika realistik adalah pembelajaran yang harus diterapkan di sekolah. Pendekatan matematika realistik merupakan suatu pendekatan belajar matematika yang dikembangkan untuk mendekatkan matematika kepada siswa (Aisyah, 2007).

Rahayu (2010) mengemukakan bahwa pendidikan matematika realistik merupakan suatu pendekatan pembelajaran matematika yang lebih menekankan realitas dan lingkungan sebagai titik awal dari pembelajaran. Selain itu, RME menekankan pada keterampilan proses matematika, berdiskusi dan berkolaborasi, beragumentasi 
dengan teman sekelas sehingga mereka dapat menemukan sendiri dan akhirnya menggunakan matematika untuk menyelesaikan masalah baik secara individu maupun kelompok.

Gravemeijer (Hobri dalam Ningsih, mengungkapkan tiga prinsip kunci RME, yaitu:

1. Guided Reinvention Through Progressive Mathematizing, pada prinsip ini siswa diupayakan agar dapat menemukan sendiri berbagai konsep, prinsip matematika dan lain-lain. Dalam memunculkan prinsip penemuan kembali, guru yang membuat bahan ajar harus menemukan situasi-situasi yang dapat membuat siswa merasa untuk menemukan hasil berpikir secara sistematis.

2. Fenomena didaktik (Didactical Phenomenology), dalam mempelajari konsep, prinsip dan materi matematika lainnya, siswa perlu dihadapkan pada permasalahan kontekstual.

3. Pengembangan model mandiri (self developed models), melalui permasalahan kontekstual siswa mampu mengubah situasi real ke situasi yang konkrit, dimana siswa mampu membuat model dalam menyelesaikan masalah.

Selain memudahkan siswa dalam memahami persoalan matematika, model pembelajaran RME ini pun harus mampu meningkatkan kemampuan komunikasi matematis siswa. Menurut hasil penelitian yang dilakukan oleh Bunga, dkk (2016) yang dilakukan terhadap beberapa siswa yang tinggal di Kecamatan Sumedang Utara. Hasilnya menunjukkan bahwa siswa belum mampu menyelesaikan soal-soal yang berkaitan dengan kemampuan komunikasi matematis. Hal ini terlihat dari rata-rata nilai yang diperoleh yaitu sebesar 36,36. Perolehan rata-rata nilai ini cukup untuk mengindikasikan bahwa kemampuan komunikasi siswa masih cukup rendah. Selain itu, hasil ujicoba yang pernah dilakukan dalam penelitian Lugina (2015) dan Handawati (2015), hasil yang sama menunjukkan bahwa kemampuan komunikasi siswa cukup rendah. Rendahnya kemampuan komunikasi matematis tersebut disebabkan karena kurang optimalnya pendekatan yang dilakukan guru di kelas saat pembelajaran matematika. Padahal menurut McNeil (Effendi, 2017) tujuan SMK adalah SMK harus inovatif progresif yang mengembangkan konten, sikap kerja, keterampilan komunikasi, serta pengetahuan matematika dan sains. Sehingga kemampuan komunikasi termasuk hal yang penting untuk dimiliki siswa tingkat SMK.

Dalam kaitannya permasalahan diatas, selain pentingnya penerapan model pembelajaran RME di tingkat SMK, bahan ajar yang digunakan oleh guru dan siswapun harus memuat nilai-nilai atau karakter RME yang bertujuan untuk meningkatkan kemampuan komunikasi matematis siswa. Tujuan dari penelitian ini adalah untuk mengetahui bagaimana penerapan model pembelajaran RME dapat meningkatkan kemampuan komunikasi matematis siswa SMK.

\section{Kemampuan Komunikasi Matematis Siswa}

Menurut Roger (Sunata dalam Nugraha, 2013) komunikasi dimaknai sebagai proses para partisipan/peserta saling berbagi informasi satu sama lain guna mencapai pengertian timbal balik. Sedagkan menurut Mulyadiana (Agisti dalam Nugraha, 2013) komunikasi merupakan salah satu keterampilan proses, yaitu berkaitan dengan kemampuan siswa dalam menyampaikan atau menerima gagasan/ide agar lebih kreatif, baik melalui lisan maupun tulisan.

Baroody (Ansari dalam Nugraha, 2013) mengungkapkan bahwa komunikasi adalah kemampuan siswa yang dapat diukur melalui aspek-aspek:

1. Representasi (Representing) adalah menjelaskan kembali suatu masalah atau ide, diagram, dan simbol menggunakan kata-kata.

2. Mendengar (listening) merupakan sebuah aspek yang sangat penting ketika berdiskusi. Begitupun dalam kemampuan komunikasi, mendengar merupakan aspek yang sangat penting untuk dapat terjadinya komunikasi yang baik.

3. Membaca (Reading) adalah aktivitas membaca secara aktif untuk mencari jawaban atas pertanyaan yang telah disusun.

4. Diskusi (discussing) adalah cara yang baik bagi siswa untuk menjauhi ketidak-konsistenan, atau suatu keberhasilan kemurnian berpikir. Selain itu, dengan diskusi dapat meningkatkan kemampuan berpikir kritis.

5. Menulis (writing) adalah suatu aktivitas yang dilakukan dengan sadar untuk mengungkapkan dan merefleksikan pikiran. Dimana siswa merangkum hasil pemikiran dan diskusinya yang dituangkan ke dalam kertas, sehingga dapat mudah dipelajari dan diingat.

Sementara itu kemampuan komunikasi matematis adalah kemampuan siswa dalam menyampaikan ide matematika baik secara lisan maupun tulisan . Kemampuan komunikasi matematis peserta didik dapat dikembangkan melalui proses pembelajaran di sekolah, salah satunya adalah proses pembelajaran matematika. Hal ini terjadi karena salah satu unsur dari matematika adalah ilmu logika yang mampu mengembangkan kemampuan berpikir siswa. Dengan demikian, matematika memiliki peran penting terhadap perkembangan kemampuan komunikasi matematisnya (Hodiyanto, 2017). 
Dari uraian diatas dapat disimpulkan bahwa kemampuan komunikasi matematis sangat penting untuk dimiliki siswa karena dengan kemampuan komunikasi matematis ini siswa dapat mengembangkan kemampuan berpikir. Indikator kemampuan komunikasi matematis yang diguanakan dalam penelitian ini adalah indikator kemampuan matematis menurut NTCM (Supandi dkk, 2017) yaitu sebagai berikut:

1. Mengorganisasi dan mengkonsolidasikan pemikiran matematika dan mengkomunikasinya kepada siswa lain.

2. Mengekspresikan ide-ide matematika dengan jelas kepada guru, teman dan lainnya.

3. Memperluas pengetahuan matematika dengan cara berdiskusi dan memikirkan strategi dengan siswa lain.

4. Menggunakan keterampilan membaca, mendengar, dan menulis untuk menginterpretasikan dan mengevaluasi gagasan matematis.

5. Menggunakan bahasa matematika secara tepat dalam berbagai situasi matematika.

\section{METODE}

Metode penelitian yang digunakan adalah metode kualitatif dengan jenis penelitian kepustakaan. Jenis penelitian kepustakaan yaitu penelitian yang dilakukan dengan cara pengumpulan informasi dari berbagai artikel, jurnal maupun literasi ilmiah lainnya yang relevan, untuk menemukan landasan teori pada penelitian yang dilakukan.

\section{HASIL DAN PEMBAHASAN}

Dalam menerapkan metode atau model pembelajaran, selain RPP dibutuhkan juga bahan/sumber ajar untuk menunjang dalam pelaksaan penerapan metode/model pembelajaran. Biasanya bahan ajar yang digunakan berupa lembar kerja siswa. Lembar kerja siswa adalah sumber belajar penunjang yang dapat meningkatkan pemahaman siswa yang harus mereka kuasai. LKS merupakan alat bantu untuk menyampaikan pesan kepada siswa yang digunakan oleh guru dalam proses pembelajaran. Penggunaan media pembelajaran berupa LKS ini akan memudahkan guru dalam menyampaikan materi pembelajaran dan mengefektifkan waktu, serta akan menimbulkan interaksi antara guru dengan siswa dalam proses pembelajaran (Senam, 2008).

Menurut Widjajanti (2008) LKS yang disusun dapat dirancang dan dikembangkan sesuai dengan kondisi dan situasi kegiatan pembelajaran yang akan dihadapi. LKS juga merupakan media pembelajaran, karena dapat digunakan secara bersama dengan sumber belajar atau media pembelajaran yang lain. LKS menjadi sumber belajar dan media pembelajaran tergantung pada kegiatan pembelajaran yang dirancang.

Berdasarkan beberapa pendapat diatas, dapat disimpulkan bahwa LKS dapat digunakan sebagai bahan/sumber belajar dalam penerapan metode pembelajaran RME, agar dalam proses pembelajaran di kelas menjadi lebih terarah dan efektif. Dalam penelitian inimateri yang digunakan yaitu mengenai aturan sinus dan cosinus untuk siswa SMK kelas X semester 2 .

Horbi (Ningsih, 2014) mengemukakan karakter RME yaitu:

1. Menggunakan masalah kontekstual (the use of contex). Pembelajaran dimulai dengan menggunakan masalah kontekstual untuk dieksplorasi, kemudian siswa membahasakan permasalahan kontekstual ke dalam bahasa matematika

2. Menggunakan model (use models, bridging by verti instruments). Model disini sebagai suatu jembatan antara real dan abstrak yang membantu siswa belajar matematika pada level abstraksi yang berbeda, sehingga siswa dapat memahami level yang satu ke level pemahaman yang lain.

3. Menggunakan kontribusi siswa (student contribution). Kontribusi yang besar pada proses belajar mengajar diharapkan datangnya dari siswa, dimana siswa mengkontuksikan sendiri proses penyelesaian masalah yang menjadi awal proses matematisasi.

4. Interaktivits (interactivity). Interaksi antarsiswa dengan guru merupakan hal yang mendasar dalam RME. Denagn bentuk-bentuk interaksi yang berupa negosiasi, penjelasan, pembenaran, setuju, tidak setuju, pertanyaan atau refleksi sehingga siswa dapat mencapai bentuk formal dari bentuk-bentuk informal.

5. Terintegrasi dengan topik lainnya (intertwining), yaitu adanya keterkaitan antara berbagai bagian dalam materi pembelajaran matematika, sehingga membantu siswa untuk mempelajari matematika secara efektif.

Maka dari itu unsur pertama yang hsdarus adalah dalam LKS tersebut adalah adanya masalah kontekstual.

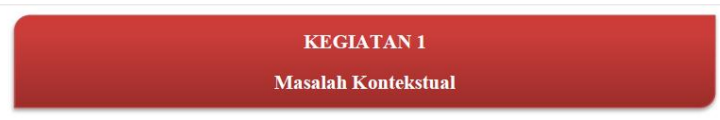

Dua kapal A dan B meninggalkan suatu pelabuhan secara bersama-sama Kapal A berlayar dengan arah $25^{\circ}$ dan kecepatan $8 \mathrm{~km} / \mathrm{jam}$, sedangkan kapal B berlayar dengan arah $145^{\circ}$ dengan kecepatan $12 \mathrm{~km} / \mathrm{jam}$. Berapa jarak kedua kapal tersebut setelah berlayar selama 2 jam?

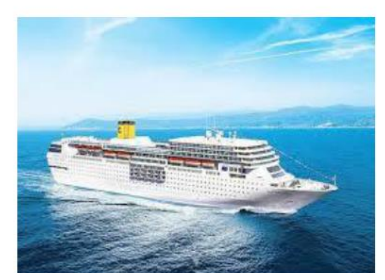




\section{Gambar 1. Masalah kontekstual}

Pada gambar diatas peserta didik diberikan suatu permasalahan kontekstual, sehingga siswa dapat lebih mudah untuk membayangkan bagaimana keadaan dalam permasalahan tersebut. Kapal dan Pelabuhan merupakan hal yang sudah mereka kenal sejak lama. Serta di dalam permasalah tersebut terdapat unsur trigonometri, yaitu arah berlayarnya kapal-kapal tersebut menggunakan derajat.

Selain memuat masalah kontekstual, LKS yang memuat unsur RME pun harus mampu menciptakan suatu kegiatan terarah yang dapat membangun kemampuan komunikasi matematis siswa. Siswa harus dibentuk menjadi beberapa kelompok agar memudahkan mereka dalam berdiskusi, membaca dan hal yang lainnya yang dapat mengumpulkan berbagai informasi dari permasalahan sehingga siswa dapat menarik kesimpulan secara matematis.
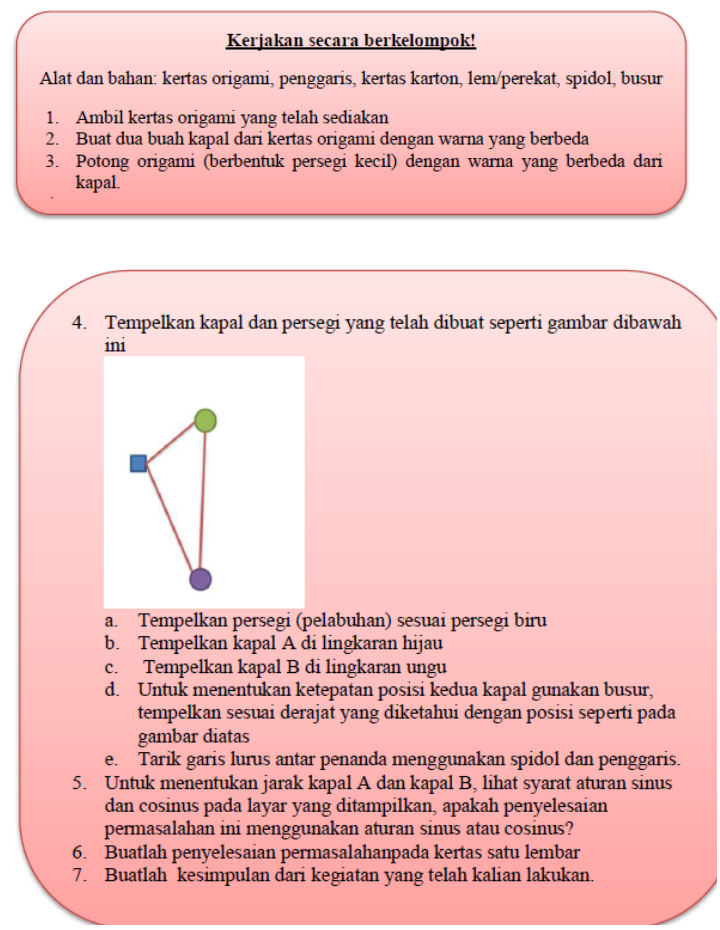

Gambar 2. Penyelesaian masalah secara berkelompok

Pada gambar diatas dijelaskan langkah-langkah penyelesaian masalah secara sistematis, untuk dikerjakan secara kelompok. Pada tahap ini siswa diarahkan untuk membuat suatu alat peraga/ilustrasi untuk memudahkan dalam menyelesaikan permasalahan. Siswa diperkenalkan dengan strategi pembelajaran yang dipakai, diarahkan untuk mengidentifikasi konsep matematika yang relevan dengan masalah serta secara bertahap meninggalkan situasi nyata menuju situasi matematika, hingga dapat menyelesaikan masalah secara matematis dan menerjemahkan kembali ke dalam solusi nyata (Septina et al., 2018).

Menurut Ansari (Hodiyanto, 2017) untuk mengukur kemampuan komunikasi matematis siswa dalam pembelajaran matematika dapat dilakukan dengan pemberian soal uraian yang bisa mengungkapkan kemampuan komunikasi matematis.

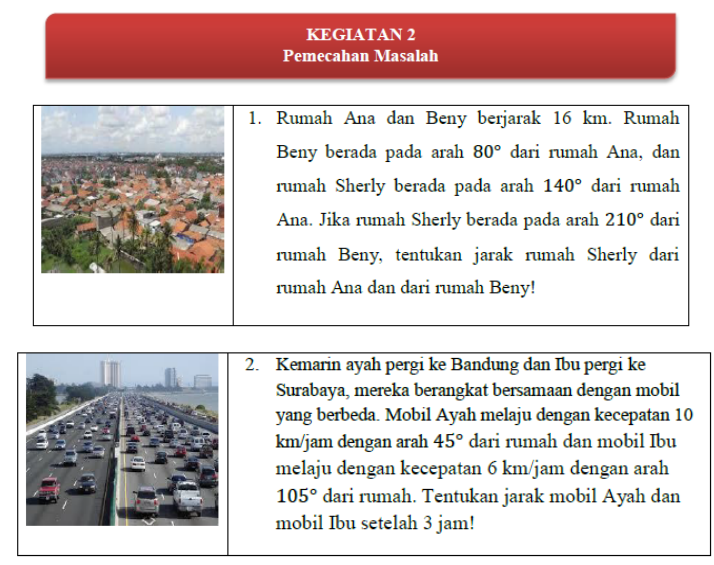

Gambar 3. Soal uraian

Pada gambar diatas diberikan dua buah soal uraian dengan dua permasalahan yang berbeda. Sehingga permasalahan yang disajikan variatif berdasarkan kondisi yang biasa siswa temui pada kehidupan nyata, yaitu tentang letak rumah dan posisi dua buah mobil.

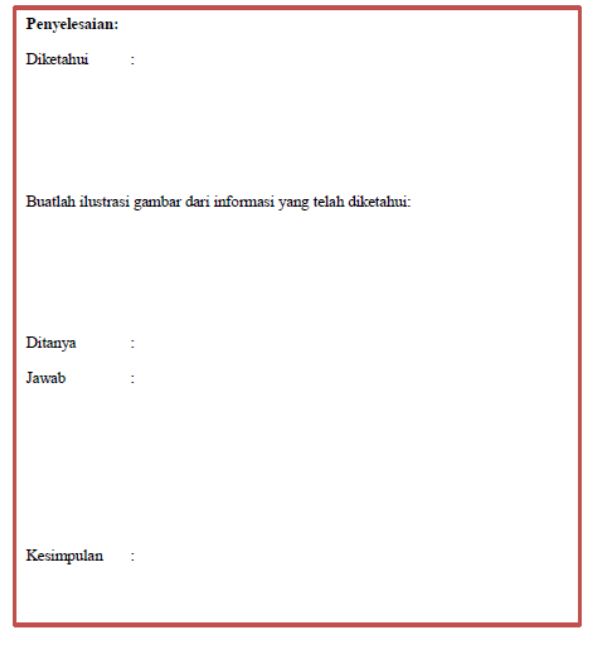

Gambar 4. Lembar penyelesaian masalah

Pada gambar diatas diberikan kolom untuk kegiatan pemecahan masalah, kolom tersebut memudahkan siswa untuk menyelesaikan masalah secara sistematis. Serta sebagai salah satu proses meningkatkan kemampuan komunikasi matematis siswa, karena selain mampu berkomunikasi secara lisan dengan berdiskusi secara berkelompok siswa juga harus mampu menyelesaikan masalah secara tulisan.

Dalam model pembelajaran RME ini siswa diharap mampu menigkatkan kemampuan komunikasi matematis, 
sehingga siswa berperan aktif dalam setiap proses pembelajaran serta memudahkan siswa dalam memahami setiap materi.

\section{PENUTUP \\ Simpulan}

Model pembelajaran RME pada dasarnya merupakan pemanfaatan realistik dan lingkungan untuk melancarkan proses pembelajaran matematika, hingga tercapainya tujuan pembelajaran yang lebih baik daripada sebelumnya. Model pembelajaran RME menggunakan masalah kontekstual sebagai titik tolak dalam belajar. Dengan berbantu bahan ajar berupa LKS memudahkan guru untuk mengarahkan siswa dalam proses pembelajran, sehingga menjadi lebih terarah dan efektif. Dengan digunakannya LKS ini langkah-langkah RME dapat diterapkan dengan baik serta mampu meningkatkan kemampuan komunikasi matematis siswa melalui sederet aktivitas yang telah disusun.

\section{Saran}

Dari penelitian ini diharapkan dapat membantu dalam proses pembelajaran matematika realistik dikelas serta adanya penelitian lanjut agar pembelajaran matematika realistik menjadi lebih baik terutama dalam meningkatkan kemampuan komunikasi matematis siswa.

\section{DAFTAR PUSTAKA}

Bunga, non dkk. 2016. Pendekatan Realistic Mathematics Education Untuk Meningkatkan Kemampuan Koneksi dan Komunikasi Matematis Siswa. Jurnal Pena Ilmiah UPI. Vol.1, No.1 (2016). Diperoleh dari https://ejournal.upi.edu/index.php/penailmiah/article/ download (diunduh 8 Mei 2020)

Effendi, Mahfud. 2017. Reposisi Pembelajaran Matematika di SMK. SemNasMat 2017. Diperoleh dari http://eprints.umm.ac.id/36850/23 (diunduh 9 Mei 2020)

Hodiyanto. 2017. Kemampuan komunikasi Matematis dalam Pembelajaran Matematika. AdMathEdu. Vol.7 No.1. Juni 2019. Diperoleh dari http://journal.uad.ac.id/index.php/AdMathEdu/article /view (diunduh 8 Mei 2020)

Agustiana, N., Supriadi, N., \& Komarudin, K. (2019). Meningkatkan Kemampuan Penalaran Matematis dengan Penerapan Pendekatan Bridging Analogy Ditinjau dari Self-Efficacy. Inovasi Pembangunan: Jurnal Kelitbangan, 7(1), 61-61.
Karyanti, K., \& Komarudin, K. (2017). Pengaruh Model Pembelajaran Kumon Terhadap Pemahaman Matematis Ditinjau Dari Gaya Kognitif Peserta Didik Pada Mata Pelajaran Matematika Kelas VIII SMP Negeri Satu Atap 4 Pesawaran. Prosiding Seminar Nasional Matematika Dan Pendidikan Matematika, 1, 89-94.

Ningsih, S. (2014). Realistic mathematics education: Model alternatif pembelajaran matematika sekolah. Jurnal Pendidikan Matematika, 1(2), 73-94.

Septina, N., Farida, F., \& Komarudin, K. (2018). Pengembangan lembar kerja siswa dengan pendekatan saintifik berbasis kemampuan pemecahan masalah. Jurnal Tatsqif, 16(2), 160-171. https://doi.org/10.20414/jtq.v16i2.200

Suherman, S., Komarudin, K., Rosyid, A., Aryanita, S., Asriyanto, D., Aradika Putra, T., \& Anggoro, T. (2018). Improving Trigonometry Concept Through STEM (Science, Technology, Engineering, and Mathematics) Learning. International Conference On Multidisciplinary Academic (ICMA).

Ningsih, seri. 2014. Realistic Mathematics Education: Model Alternatif Pembelajaran Matematika Sekolah. JPM IAN Antasari. Vol. 01. No. 2 Januari-Juni 2014. Hal. 73-74. Diperoleh dari http://jurnal.uinantasari.ac.id/index.php/jpm/article/view (diunduh 8 Mei 2020)

Nugraha, A. 2013. Pembelajaran Matematika Melalui Metode Personalized System of Instruction (PSI) untuk Meningkatkan Kemampuan Komunikasi Matematis Siswa SMP. Skripsi. Fakultas Keguruan dan Ilmu Pendidikan Universitas Pendidikan Indonesia

Nurjanatin, ina dkk. 2017. Analisis Kesalahan Peserta Didik dalam Menyelesaikan Soal Cerita pada Materi Luas Permukaan Balok di Kelas VIII-F Semester II SMP Negeri 2 Jaya Pura. Jurnal Ilmiah Matematika dan Pembelajarannya. Vol.2, No.1, Juli 2017, hal 2231. Diperoleh dari https://ejournal.uncen.ac.id/index.php/article/ download (diunduh 14 Mei 2020)

Rahayu, Tika. 2010. Pengaruh Pendekatan RME (Realistic Mathematics Education) terhadap Peningkatan Prestasi Belajar Matematika Siswa Kelas II SD Negeri Penaburuban 1 Perbalingga. Skripsi. Diperoleh dari http://repository.ump.ac.id/7232/2 (diunduh 8 Mei 2020) 
Senam, dkk. Efektifitas Pembelajaran Kimia untuk Siswa SMA Kelas XI dengan Menggunakan LKS Kimia Berbasis Life Skill. Diperoleh dari http://jurnal.pdii.lipi.go.id/admin/jurnal (diunduh 8 Mei 2020)

Widjajanti, Endang. 2008. Kualitas Lembar Kerja Siswa. Jurusan Pendidikan Kimia FMIPA UNY. Diperoleh darihttp://staff.uny.ac.id/sites/default/files/pengabdia n/endang-widjajayanti-lfx-ms-dr (diunduh $14 \mathrm{Mei}$ 2020)

Suherman, Erman dkk.2001. strategi pembelajaran matematika kontenporer. Bandung: Upi press

Supandi, dkk. 2017. Peningkatan Kemampuan Komunikasi Matematis MenggunakanStrategi ThinkTalk-Write. Jurnal Kependidikan, Vol.1, no. 2, November 2017, hal 227-239. 